\title{
WD Repeat and Coiled-Coil-Containing Protein
}

National Cancer Institute

\section{Source}

National Cancer Institute. WD Repeat and Coiled-Coil-Containing Protein. NCI Thesaurus. Code C101430.

WD repeat and coiled-coil-containing protein $(721 \mathrm{aa}, \sim 79 \mathrm{kDa})$ is encoded by the human WDCP gene. This protein plays a role in tyrosine-protein kinase HCK binding. 